\title{
Survey of orchidaceae from the State of Sergipe, Brazil
}

\author{
Silvana Helena Nascimento Monteiro ${ }^{1,3}$, Tamires Carregosa ${ }^{1}$, Luiz Aquino Silva Santos ${ }^{1}$, \\ José Elvino do Nascimento Júnior ${ }^{2} \&$ Ana Paula do Nascimento Prata ${ }^{1}$ \\ ${ }^{1}$ Departamento de Biologia, Universidade Federal de Sergipe - UFS, Cidade Universitária Prof. José \\ Aloísio de Campos, Av. Marechal Rondon, s/n, Jardim Rosa Elze, CEP 49100-000, \\ São Cristóvão, SE, Brazil \\ ${ }^{2}$ Programa de Pós-Graduação em Biologia Vegetal, Instituto de Biologia, Universidade Estadual de \\ Campinas - UNICAMP, Rua Monteiro Lobato, 255, CEP 13083-970, Campinas, SP, Brazil \\ ${ }^{3}$ Corresponding author: Silvana Helena Nascimento Monteiro, e-mail: shnmonteiro@gmail.com
}

\begin{abstract}
MONTEIRO, S.H.N., SILVA, T.C., SANTOS, L.A.S., NASCIMENTO-JÚNIOR, J.E. \& PRATA, A.P.N. Survey of Orchidaceae from the state of Sergipe, Brazil. Biota Neotrop. 12(2): http://www.biotaneotropica.org.br/ v12n2/en/abstract?inventory+bn01012022012
\end{abstract}

\begin{abstract}
The state of Sergipe, located in the Northeast Region of Brazil, covers an area of 21,994 $\mathrm{km}^{2}$ and is the smallest state in the country. The vegetation of this region is predominantly caatinga, but there are also mangroves, dunes, restinga, fragments of original Atlantic Forest (which are intermingled with pastures, secondary growth, and agricultural land) and cerrado. During intensive fieldwork in Sergipe, we observed various Orchidaceae species that had not been recorded for the state, which made it necessary to update the list of species for this region. Within the state, the family is represented by 63 species and 34 genera, of which Habenaria (10 spp.) Epidendrum (4 spp.) and Encyclia (4 spp.) are highlights. Orchidaceae species from this region are generally terrestrial and occur in grasslands (59\%, 37 of $63 \mathrm{spp}$.). The remaining species are epiphytes (21 spp.) and hemiepiphytes ( $3 \mathrm{spp}$.). The majority of the species flower at the beginning of the rainy season. Of the 61 species that were recorded during this study, 34 species are new records for the state of Sergipe. This work includes a list of the species of Orchidaceae from Sergipe, and provides data about the phenology and habitat for each taxon. Keywords: plants of the Northeast, inventory, plant biodiversity.
\end{abstract}

MONTEIRO, S.H.N., SILVA, T.C., SANTOS, L.A.S., NASCIMENTO-JÚNIOR, J.E. \& PRATA, A.P.N. Levantamento da família Orchidaceae no estado de Sergipe. Biota Neotrop. 12(2): http://www.biotaneotropica. org.br/v12n2/pt/abstract?inventory+bn01012022012

Resumo: O estado de Sergipe, localizado na região Nordeste do Brasil, abrange uma área de $21.994 \mathrm{~km}^{2}$, sendo o menor da federação. A cobertura vegetal predominante do estado é representada pela Caatinga, mas encontra-se também vegetação de mangue, dunas, restingas, fragmentos florestais, originários da Mata Atlântica, entremeados por áreas de pastagens, capoeiras e áreas agrícolas, além de formações de Cerrado. A partir de um intenso trabalho de campo, observou-se a ocorrência de diversas Orchidaceae ainda não catalogadas para o estado, portanto, fazendo-se necessária a atualização na listagem das espécies ocorrentes em Sergipe. A família está representada no estado por 63 espécies subordinadas a 34 gêneros, dentre os quais se destacam: Habenaria (10 spp.) Epidendrum (4 spp.) e Encyclia (4 spp.). As espécies encontradas ocorrem principalmente nas formações campestres (59\%, 37 de 63), o que explica a predominância da forma de vida terrestre. As demais espécies estão distribuídas em epífitas (21 spp.) e hemiepífitas ( $3 \mathrm{spp}$.). A maioria das espécies floresce no início do período chuvoso. Dentre as 63 espécies encontradas 34 são novas ocorrências para o estado de Sergipe. Este trabalho inclui listagem das espécies ocorrentes em Sergipe, assim como dados fenológicos e habitat.

Palavras-chave: plantas do nordeste, inventário, biodiversidade vegetal. 


\section{Introduction}

Orchidaceae comprise approximately $40 \%$ of the monocotyledons, and are considered by many authors as the largest family of angiosperms (Dahlgren et al. 1985, Atwood 1986, Dressler 1993). Atwood (1986) estimates that the family possesses 24,500 species worldwide, which are mostly native to tropical regions. The most significant revision of Brazilian Orchidaceae suggests that there are 2350 species in the country (Pabst \& Dungs 1975, 1977); however, a recent publication lists 2419 species (Barros et al. 2010). According to Hoehne (1949), species of Orchidaceae can be found in every vegetation type in Brazil.

The majority of the floristic works about Orchidaceae of Brazil have concentrated on the Southern and Southeast regions of the country. For the Northeast Region, there are very few studies about the occurrence and distribution of the family, and for many states the only information available is in the last Brazilian checklist of Orchidaceae (Pabst \& Dungs 1975, 1977).

For the state of Sergipe, the most recent information about native orchids can be found in the Catálogo de Plantas e Fungos do Brasil (Barros et al. 2010). This work is based on collections from the main herbaria in the country as well as lists of Orchidaceae that were previously compiled by specialists, and, for this reason, underestimates the number of species that occur in many states.

Although Sergipe is the smallest state in Brazil $\left(21.918 \mathrm{~km}^{2}\right)$, which primarily has a semi-arid climate, it possesses a diverse flora represented by different phytophysiognomies, for example, coastal vegetation, Atlantic Forest, caatinga, and savanna (Franco 1983). According to the checklists published by Pabst \& Dungs (1975, 1977) and Barros et al. (2010), the number of orchids recorded for the state is six and 22, respectively. Besides these works, there are no other studies that include additional species.

Based on recent collections and specimens in local herbaria, it was discovered that the number of Orchidaceae species recorded for Sergipe was not accurate. Therefore, the goals of this study were to survey the Orchidaceae of Sergipe and to create an updated list of species that occur in the different vegetation types of this state.

\section{Materials and Methods}

Sergipe occupies an area of 21,918 $\mathrm{km}^{2}$, and shares its border with Alagoas (to the north), Bahia (to the west and south), and the Atlantic Ocean (to the east). The vegetation cover in Sergipe is composed principally of steppe savanna (caatinga), seasonal semi-deciduous forest (secondary Atlantic Forest fragments), pioneer formations (restinga and mangroove), grasslands (cerrado), and areas of ecological transition (steppe savanna/seasonal forest, savanna/ seasonal forest and savanna/steppe savanna); however, the majority of the vegetation cover in the sate has been altered by agricultural activities and other human disturbances (classification based on Instituto... 1992). Although IBGE (Instituto Brasileiro de Geografia e Estatística) provides a comprehensive map of the vegetation cover of Brazil, the classification used in the map does not include some regional formations, such as open formations with white-sand soils, which occur in Parque Nacional da Serra de Itabaiana, in Sergipe, and are in transition areas with seasonal, semi-deciduous forest. The white-sand formations have sedimentary, yellowish white, sandy soils with an herb-shrub to shrub-tree vegetation that occurs at lower elevations than the grasslands (Dantas \& Ribeiro 2010). In addition, the IBGE map does not include (for the sate of Sergipe) the islands of montane, seasonal, semi-deciduous forest that are in the areas of caatinga. In the Northeast Region of Brazil, the wet, high altitude forests are enclaves of humid Atlantic Forest that are in the middle of the semi-arid region (Tabarelli \& Santos 2004), commonly known as brejos de altitude. This forest type is encountered in the Serra da Guia, in the municipality of Poço Redondo, in the northeastern part of the state (Machado, W. dados não publicados).

The inventory of Sergipe was conducted via random monthly samples at different times of the year, from December 2008 to December 2010, and surveyed the major vegetation types in the municipalities visited (Figure 1). As a result of human disturbance and exploitation of the land, the vegetation in Sergipe is in an advanced stage of degradation. For this reason, the municipalities selected for this study were those with remnants of original vegetation that were well preserved.

In addition, specimens were examined from herbaria at the Universidade Federal de Sergipe (ASE), Universidade Estadual de Feira de Santana (HUEFS), Universidade Federal da Bahia (ALCB), IBGE (HRB - RADAMBRASIL-BA) and Companhia Hidro-Elétrica do São Francisco (Herbário Xingó, which is not listed in Index Herbariorum), and the collections of the Universidade Federal de Minas Gerais (BHCB) and Universidade Federal do Ceará (EAC) were searched using Species-link do Centro de Referências em Informação Ambiental (CRIA). During fieldwork, plants were collected and information was recorded about their life form (according to Bechtel et al. 1998), phenology and the habitat where they grow. Sterile species were collected and cultivated (until they flowered) in the garden of the Departamento de Biologia at the Universidade Federal de Sergipe. All specimens, including those that flowered in cultivation, were deposited in ASE.

To identify the species, specialists in the family and Pabst \& Dungs (1975, 1977), Cogniaux (1893-1896, 1898-1902, 1904-1906), Hoehne (1940, 1942, 1945, 1949, 1953), and Toscano-de-Brito $\&$ Cribb (2005) were consulted. The subfamilies and subtribes recognized in this work are based on Chase et al. (2003).

\section{Results and Discussion}

This inventory recorded 63 species of Orchidaceae (Table 1, Figure 2-3), distributed in three subfamilies, 11 subtribes and 34 genera. Vanilloideae, with four species in two genera, represented $7 \%$ of the total species. Orchidoideae, with 18 species in seven genera and three subtribes, represented $29 \%$ of the total species. Epidendroideae, with 41 species in 24 genera and eight subtribes, represented $64 \%$ of the total species. The main flowering periods were between January and March, and September and December, which corresponded to the beginning and end of the rainy season.

Of the species recorded, the predominant life form was terrestrial (37 spp., 59\%), 37\% were epiphytes (23 spp.) and 4\% were hemiepiphyes (3 spp.). Encyclia alboxanthina Fowlie and Brassavola tuberculata Hook., were encountered as terrestrial/ rupicolous and epiphytic/rupicolous, respectively. The high proportion of terrestrial species is probably because of the vast field formations (grasslands) found in the state, which are natural or the result of human activity. The genus with the most species was 


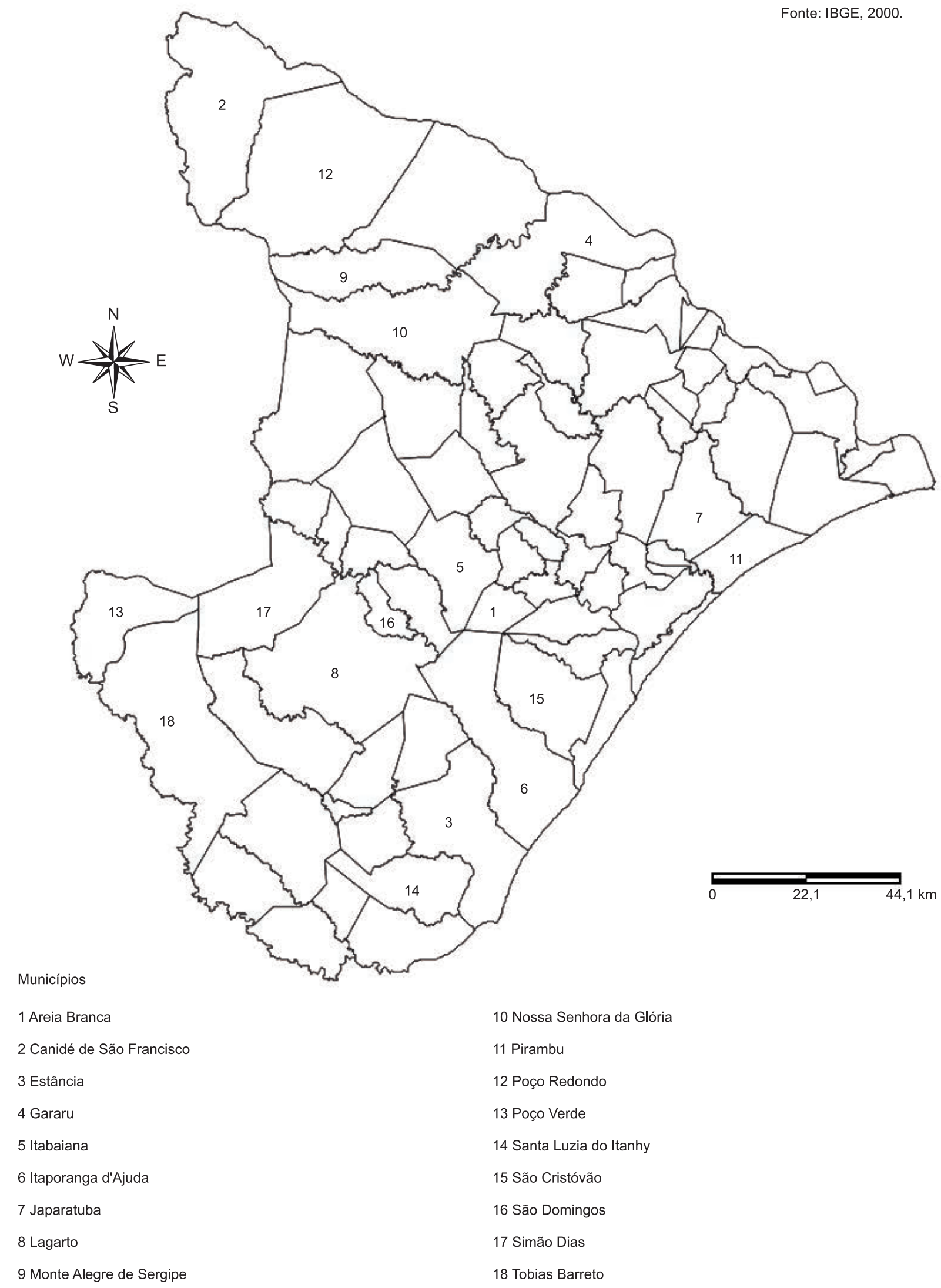

Figure 1. Map showing the municipalities visited during the Survey of Orchidaceae in Sergipe. 


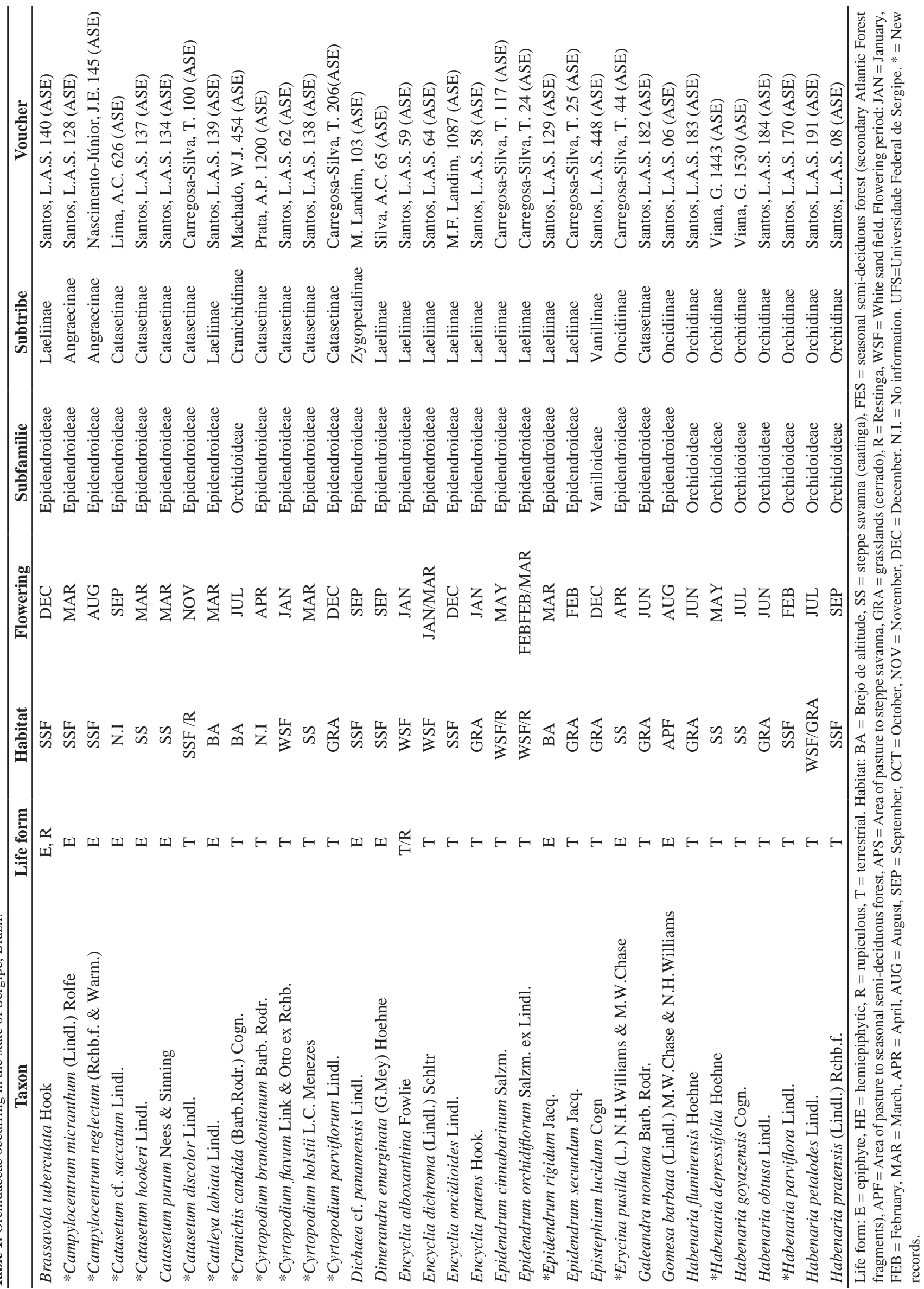




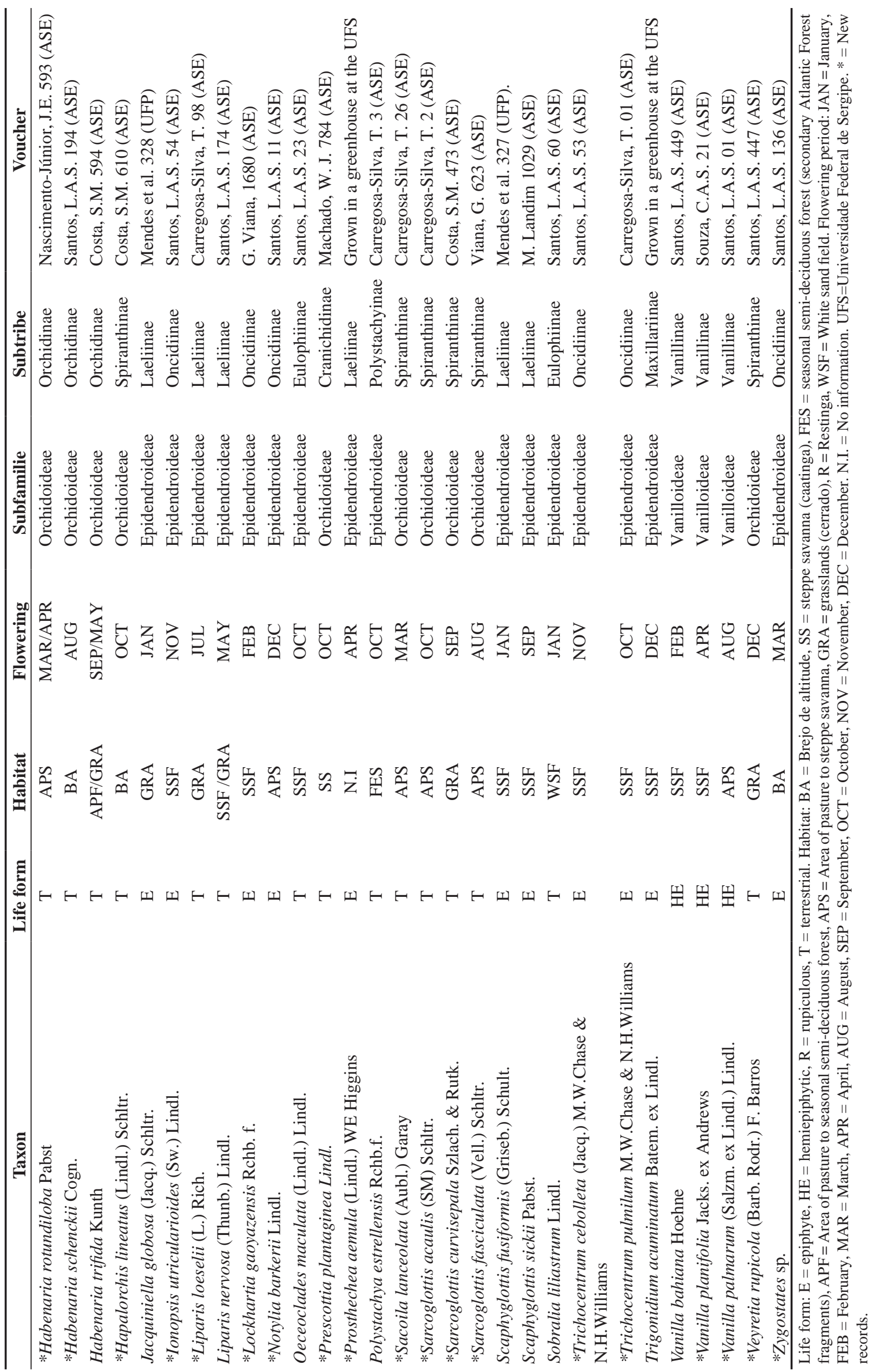




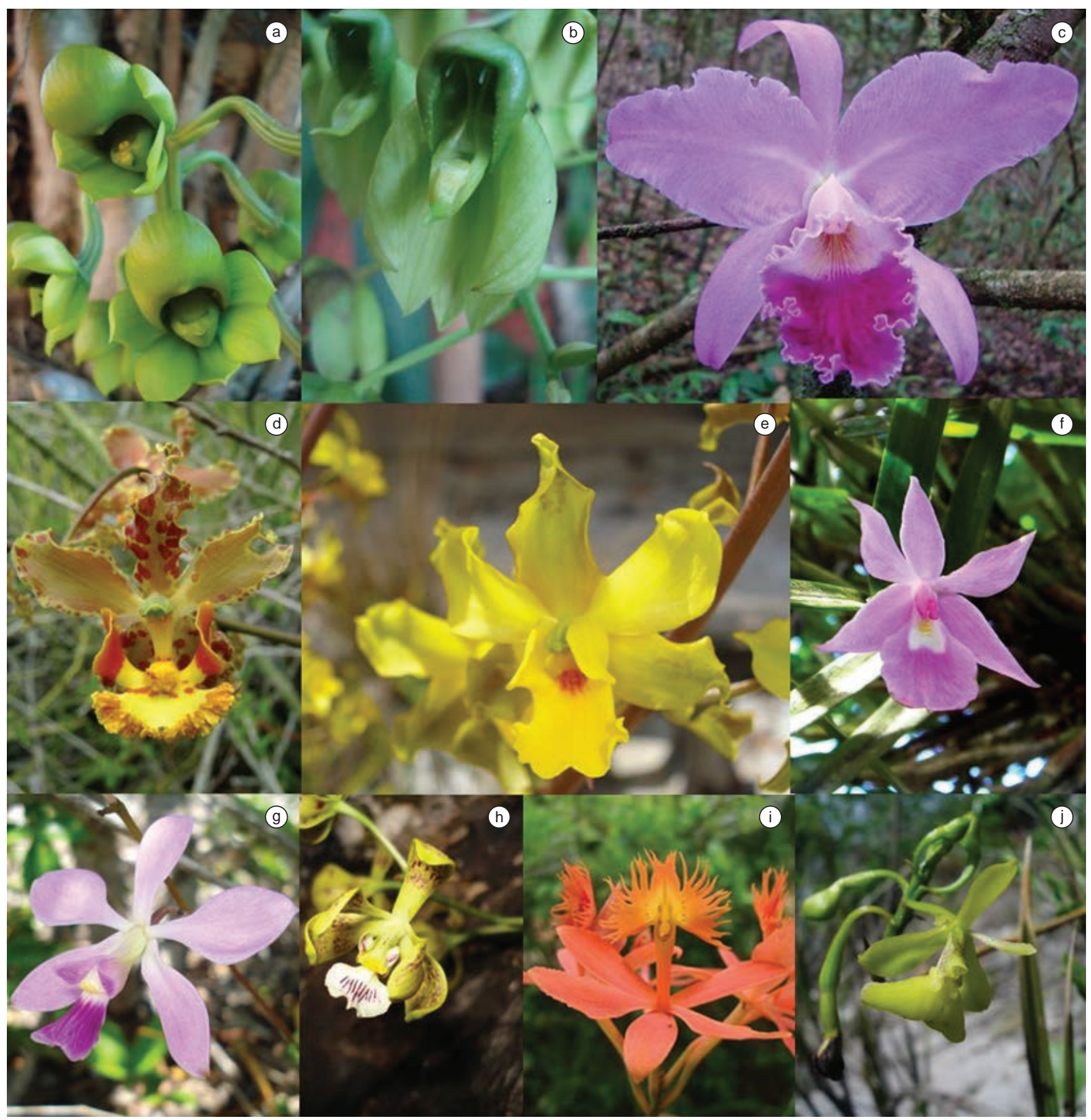

Figure 2. Some species of orchids in Sergipe. a. Catasetum hookeri, b. Catasetum purum, c. Cattleya labiata, d. Cyrtopodium holstii, e. Cyrtopodium polyphyllum, f. Dimerandra emarginata, g. Encyclia dichroma, h. Encyclia oncidioides, i. Epidendrum cinnabarinum, j. Epidendrum orchidiflorum. Photos: SHNM (a,b,e,g,h,j), LASS (c,d,i) e TCS (f).

Habenaria (10 spp.), which was very common in fields (Batista \& Bianchetti 2003, Batista et al. 2005, Rocha \& Waechter 2006).

Of the 63 species recorded, 29 have already been cited for the state (see Barros et al. 2010; Pessoa \& Alves 2011). The remaining species (34 spp., see Table 1) are cited for the first time for Sergipe. Encyclia advena (Rchb.f.) Porto \& Brade, Encyclia bohnkiana V.P.Castro \& Campacci, Encyclia osmantha (Barb.Rodr.) Schltr., Habenaria josephensis Barb.Rodr., Leochilus labiatus (Sw.) Kuntze, Liparis vexillifera (Llave \& Lex.) Cogn. and Trichocentrum fuscum
Lindl., cited in Barros et al. (2010) for Sergipe, were not encountered during the fieldwork of this study, the review of specimens, or during the search for taxa in the Species Link database. This is probably because some of the species listed by Barros et al. (2010) came from misidentified collections (which was observed during the current study) based on previously compiled lists.

The 34 species that are new records for the state of Sergipe demonstrate how significant floristic work can be to our understanding of the biological diversity of a region, and how this type of work can 


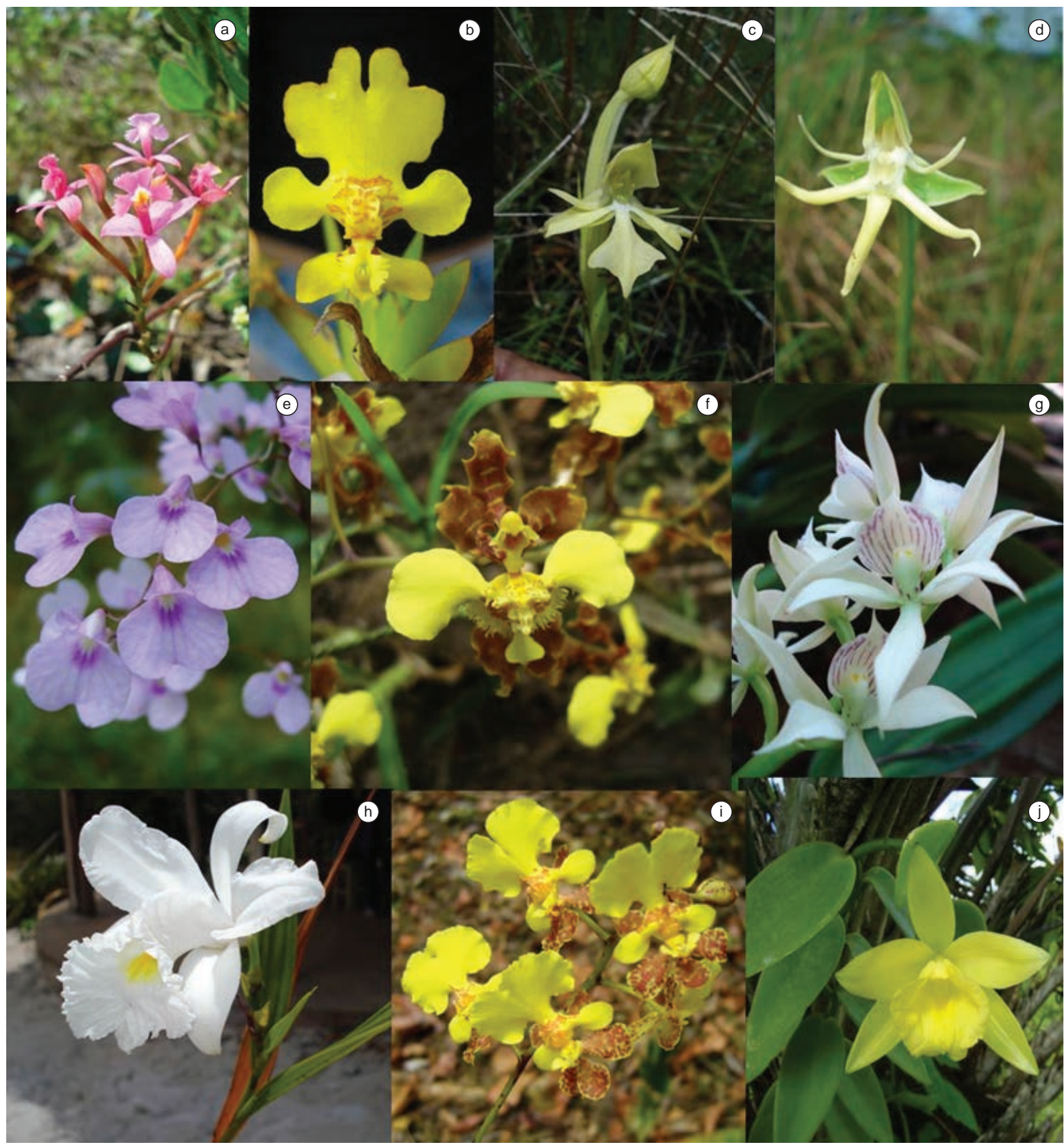

Figure 3. Some species of orchids in Sergipe. a. Epidendrum secundum, b. Erycina pusilla, c. Habenaria pratensis, d. Habenaria trifida, e. Ionopsis utricularioides, f. Gomesa barbata, g. Prosthechea aemula, h. Sobralia liliastrum, i. Trichocentrum cebolleta, j. Vanilla palmarum. (Photos: SHNM (a,c,d,g,h), LASS (e,f,i,j) e TCS (b).

contribute to our knowledge about the species and distribution of a taxonomic group.

\section{Acknowledgements}

The authors thank the Fundação de Apoio à Pesquisa e à Inovação Tecnológica do Estado de Sergipe (FAPITEC/SE) for the financial aid for the project (Edital $N^{\circ} 04 / 2008$ ), CNPq for the study grant (number 35.0148/2009.0) and TECC Editora for the translation.

\section{References}

ATWOOD, J.T. 1986. The size of the Orchidaceae and the systematic distribution of epiphytic Orchids. Selbyana 9(1):171-186.

BARROS, F., VINHOS, F., RODRIGUES, V.T., BARBERENA, F.F.V.A. \& FRAGA, C.N. 2010. Orchidaceae in Lista de Espécies da Flora do Brasil. Jardim Botânico do Rio de Janeiro, Rio de Janeiro. http://floradobrasil. jbrj.gov.br/2010/FB000179.

BATISTA, J.A.N. \& BIANCHETTI , L.B. 2003. Lista atualizada das Orchidaceae do Distrito Federal. Acta Bot. Bras. 17(2):183-201. 
BATISTA, J.A.N., BIANCHETTI, L.B. \& PELLIZZARO, K.F. 2005. Orchidaceae da Reserva Ecológica do Guará, DF, Brasil. Acta Bot. Bras. 19(2):221-232.

BECHTEL, H., CRIBB, P.J. \& LAUNERT, E. 1998. The manual of cultivated Orchid species. Blandford, London, 585p.

CHASE, M.W., CAMERON, K.M., BARRETT, R.L. \& FREUDENSTEIN, J.V. 2003. DNA data and Orchidaceae systematics: a new phylogenetic classification. In Orchid Conservation Natural History Publications (K.W. Dixon, S.P. Kell, R.L. Barrett \& P. J. Cribb, eds.). Kota Kinabalu, Sabah, p.69-89.

COGNIAUX, A. 1893-1896. Orchidaceae. In Flora brasiliensis (C.F.P. Martius, A.G. Eichler \& I. Urban, eds.). F. Fleischer, Munique, v.3, parts 4, 672p.

COGNIAUX, A. 1898-1902. Orchidaceae. In Flora brasiliensis (C.F.P. Martius, A.G. Eichler \& I. Urban, eds.). R. Oldenbourg, Munique, v.3, parts 5, 664p.

COGNIAUX, A. 1904-1906. Orchidaceae. In Flora brasiliensis (C.F.P. Martius, A.G. Eichler \& I. Urban, eds.). R. Oldenbourg, Munique, v.3, parts 6, 604p.

DAHLGREN, R.M.T., CLIFFORD, H.T. \& YEO, P.F. 1985. The families of the monocotyledons. Springer-Verlag, Berlin, 520p.

DANTAS, T.L. \& RIBEIRO, A.S. 2010. Caracterização da vegetação do Parque Nacional Serra de Itabaiana, Sergipe - Brasil. Biotemas 23(4):9-18.

DRESSLER, R.L. 1993. Phylogeny and classification of the orchid family. Dioscorides Press, Portland, 314p.

HOEHNE, F.C. 1940. Flora Brasílica. Secretaria da Agricultura, Indústria e Comércio de São Paulo, São Paulo, v.12.1, fasc.1, 254p.
HOEHNE, F.C. 1942. Flora Brasílica. Secretaria da Agricultura, Indústria e Comércio de São Paulo, São Paulo, v.12.6, fasc.5, 218p.

HOEHNE, F.C. 1945. Flora Brasílica. Secretaria da Agricultura, Indústria e Comércio de São Paulo, São Paulo, v.12.2, fasc.8, 389p.

HOEHNE, F.C. 1949. Iconografia de orquidáceas do Brasil. S. A. Indústrias Graphicars-f. Lanzara, São Paulo, 601p.

HOEHNE, F.C. 1953. Flora Brasílica. Secretaria da Agricultura, Indústria e Comércio de São Paulo, São Paulo, v.12.7, fasc.10, 396p.

INSTITUTO BRASILEIRO DE GEOGRAFIA E ESTATÍSTICA - IBGE. Departamento de Recursos Naturais e estudos ambientais. Manual técnico da vegetação Brasileira. IBGE, Rio de Janeiro, 92p. Série Manuais Técnicos em Geociências, n.1.

PABST, G.F.J. \& DUNGS, F. 1975. Orchidaceae Brasiliensis. Brucke-Verlag Kurt Schmersow, Hildeshein, v.1, 408p.

PABST, G.F.J. \& DUNGS, F. 1977. Orchidaceae Brasiliensis. Brucke-Verlag Kurt Schmersow, Hildeshein, v.2, 418p.

PESSOA, E. \& ALVES, M. 2011. Orchidaceae Juss. Na Serra de Itabaiana, Sergipe, Brasil. Rev. Caatinga 24(4):102-114.

ROCHA, F.S. \& WAECHTER, J.L. 2006. Sinopse das Orchidaceae terrestres ocorrentes no litoral norte do Rio Grande do Sul, Brasil. Acta Bot. Bras. 20(1):71-86.

TABARELLI, M. \& SANTOS, A.M.M. 2004. Uma breve descrição sobre a história natural dos brejos nordestinos. In Brejos de altitude em Pernambuco e Paraíba: história natural, ecologia e conservação (K.C. Porto, J.J.P. Cabral \& M. Tabarelli, eds.). Brasília, Ministério do Meio Ambiente, p.17-24.

TOSCANO-DE-BRITO, A.L.V. \& CRIBB, P. 2005. Orquídeas da Chapada Diamantina. Nova Fronteira, Rio de Janeiro, 400p. 